Article

\title{
Research on Green Management Effect Evaluation of Power Generation Enterprises in China Based on Dynamic Hesitation and Improved Extreme Learning Machine
}

\author{
Yunfu Qin ${ }^{1}$, Menglu Li ${ }^{1,2, *}$, Gejirifu De ${ }^{1,2}$, Liling Huang ${ }^{1,2}$, Shenbo Yang ${ }^{1,2}$, Qinkun Tan ${ }^{3}(\mathbb{D}$, \\ Zhongfu Tan ${ }^{1,2,4}$ and Fengao Zhou ${ }^{1}$ \\ 1 School of Economics and Management, North China Electric Power University, Beijing 102206, China \\ 2 Beijing Key Laboratory of New Energy and Low-Carbon Development, North China Electric Power \\ University, Beijing 102206, China \\ 3 State Grid Energy Research Institute Co., LTD., Beijing 102209, China \\ 4 School of Economics and Management, Yan'an University, Yan'an 716000, China \\ * Correspondence: 1182206095@ncepu.edu.cn; Tel.: +86-010-6177-3077
}

Received: 10 June 2019; Accepted: 16 July 2019; Published: 22 July 2019

\begin{abstract}
Carbon emissions and environmental protection issues have become the pressure from the international community during the current transitional stage of China's energy transformation. China has set a macro carbon emission target, which will reduce carbon emissions per unit of Gross Domestic Product (GDP) by $40 \%$ in 2020 and 60-65\% in 2030 than that in 2005. To achieve the emission reduction target, the industrial structure must be adjusted and upgraded. Furthermore, it must start from a high-pollution and high-emission industry. Therefore, it is of practical significance to construct a low-carbon sustainability and green operation benefits of power generation enterprises to save energy and reduce emissions. In this paper, an intuitionistic fuzzy comprehensive analytic hierarchy process based on improved dynamic hesitation degree (D-IFAHP) and an improved extreme learning machine algorithm optimized by RBF kernel function (RELM) are proposed. Firstly, we construct the evaluation indicator system of low-carbon sustainability and green operation benefits of power generation enterprises. Moreover, during the non-dimensional processing, the evaluation index system is determined. Secondly, we apply the evaluation indicator system by an empirical analysis. It is proved that the D-IFAHP evaluation model proposed in this paper has higher accuracy performance. Finally, the RELM is applied to D-IFAHP to construct a combined evaluation model named D-IFAHP-RELM evaluation model. The D-IFAHP evaluation results are used as the input of the training sets of the RELM algorithm, which simplifies the comprehensive evaluation process and can be directly applied to similar projects.
\end{abstract}

Keywords: low-carbon sustainability and green operation benefits; evaluation index system for power generation enterprises; intuitionistic fuzzy analytic hierarchy process; dynamic hesitation; improved extreme learning machine

\section{Introduction}

\subsection{Motivation}

By 2018, the standard coal consumption rate of China's $6000 \mathrm{~kW}$ and above thermal power units is $308 \mathrm{~g} / \mathrm{kWh}$, which is $1 \mathrm{~g} / \mathrm{kWh}$ lower than that of 2017 [1]. The power generation industry has always been an important research indirection for energy conservation and emission reduction. According 
to the 13th Five-Year Plan, the installed capacity of wind power and photovoltaic power generation will reach $210 \mathrm{GW}$ and $110 \mathrm{GW}$, respectively, in 2020, with an average annual growth rate of $9.9 \%$ and $21.2 \%$, respectively. Therefore, low-carbon power supply structure is an important energy-saving and emission-reduction method for power generation enterprises [2]. In order to achieve long-term planning and sustainable development, power generation enterprises must adjust the power supply structure and update low-carbon power technology [3]. On this basis, they can maximize the efficiency of energy-saving and emission-reduction operations. Although there are many studies on energy conservation and emission reduction in the power industry, they mainly focus on macroeconomy sectors and use physical indicators of energy and emissions, such as standard coal consumption per unit of power generation, enterprise electricity consumption rate, etc. These indicators can reflect the actual effect of energy conservation and emission reduction in the macroeconomy sector, but cannot comprehensively reflect the sustainable operation efficiency of power generation enterprises in microscopic indirection. Therefore, there is currently a lack of research in this indirection. At present, China is at a critical stage of energy transformation. The government's control over the clean production of traditional thermal power generation enterprises is becoming more and more strict. Many power generation companies lack the green and clean sustainable operation capability and their profits are seriously declining. Therefore, we propose evaluation indicator system of low-carbon sustainability and green operation benefits of power generation enterprises to obtain the direction and signal of future profit margins.

In summary, the research goal of this paper is as follows.

1. Putting forward a new concept of low-carbon sustainability and green operation benefits for power generation enterprises, which is different from the previous single-generation clean production evaluation of power generation enterprises, and the focus is more on green sustainability and market transactions.

2. The study results can provide reference for the supervision departments of the low-carbon sustainability assessment to evaluate the low-carbon sustainability and green operation in China, and then promotes energy conservation in the power generation industry.

3. Linking the clean production evaluation with sustainable profitability and promoting the indicator system to guide the transformation of power generation enterprises under the background of China's energy revolution.

\subsection{Paper Innovation}

In this paper, the main innovations are as follows.

(1) The traditional research on energy saving and emission reduction is mainly focused on the macro level, however, there are few studies on the enterprise level. Therefore, we construct an evaluation system about low-carbon sustainability and green operation benefits for power generation enterprises.

(2) Traditional fuzzy theory can only describe the two states of "positive" and "negative". Intuitionistic fuzzy set theory is an extension of fuzzy theory. The intuitionistic fuzzy set proposed in this paper also considers the state of hesitation, describing fuzzy information and uncertainty. Moreover, the information is more flexible and practical.

(3) We improve the generalization ability of the evaluation model proposed in this paper. We input the evaluation result of intuitionistic fuzzy analytic hierarchy process optimized by dynamic hesitation degree (D-IFAHP) to the training set of an improved extreme learning machine algorithm optimized by RBF kernel function (RELM) algorithm to achieve further optimization. The results of RELM training can verify the effectiveness of the proposed evaluation method. At the same time, the application of RELM algorithm will greatly improve the evaluation accuracy and the speed. 


\subsection{Structure of the Article}

The structure of this paper is as follows: Section 2 conducts literature review; Section 3 establishes the evaluation index system of energy-saving and emission-reduction sustainable operation efficiency of power generation enterprises; Section 4 introduces the intuitionistic fuzzy analytic hierarchy process of dynamic hesitation optimization and the improved principle of extreme learning machine algorithm; Section 5 verifies the validity and applicability of the evaluation model proposed in this paper by example analysis; Section 6 summarizes the research results of the full text.

\section{Literature Review}

In recent years, researchers have conducted a large number of comprehensive evaluation studies on power generation companies, such as safety production [4-6], competitiveness [7-9], and investment and operation [10-12]. Based on the dimensions and direction of index construction in the research of these papers, we extract indicators related to the low-carbon sustainability and green operation benefits of power generation enterprises. Lu [4] designed the index system from four aspects: management factors, personnel factors, environmental factors, and equipment factors. Shi et al. [5] used safety system engineering methods to measure the safety of power plants based on four aspects: personal safety, equipment safety, basic management, and on-site management. Li [6] used the three dimensions of safety production management, equipment safety, labor safety, and operating environment as the criterion layer of fuzzy analytic hierarchy process. Wei [7] considered the six criteria layers, namely the enterprise scale and its development capability, operational capability, unit power generation cost, market share, safety and reliability, and production efficiency. Li et al. [8] established an index system based on production cost, operational efficiency, auxiliary services, technical equipment, market share, and safety production. Zhang et al. [9] built an ideal evaluation framework and indicator system for comprehensive competitiveness of enterprises from two sources: external sources, internal sources. Liu [10] studied and analyzed the clean production evaluation methods and index system of thermal power industry. Ren et al. [11] used the data envelopment analysis (DEA) model to test the coordinated development efficiency and transformation trend of electric energy production and environment in China's thermal power industry. Jia et al. [12] compared main indicators of clean production in the thermal power industry and evaluated the company's clean production level in the thermal power industry and its successful clean production. Chen et al. [13] established a carbon emission calculation model adapted to different power dispatch modes and proposed to generate electricity annually. Shi [14] constructed a results-oriented quantitative power industry energy conservation and emission reduction performance evaluation index system. He et al. [15] designed a relationship diagram between energy-saving performance and emission reduction performance and a triangular diagram of coordination performance between energy-saving performance, emission-reduction performance, and economic benefit. Liu [16] applied the improved Technique for Order Preference by Similarity to an Ideal Solution (TOPSIS) to establish a comprehensive evaluation model for energy saving and emission reduction effects of power grid enterprises. Zhu [17] combined qualitative indicators with quantitative indicators, and constructed indicators based on fuzzy analytic hierarchy process. Zhao [18] constructed the performance evaluation index system and evaluation model for energy saving and emission reduction and used fully arranged polygon graphic index method to conduct static evaluation research and dynamic evaluation research with systematic evidence.

The methods of comprehensive evaluation mainly include analytic hierarchy process, sequential relationship method, entropy weight method, fuzzy theory, matter element expansion method, and TOPSIS. In recent years, the fuzzy theory has been widely used in comprehensive evaluation in various fields [19-24]. Therefore, based on the validity of these studies, we attempt to introduce fuzzy theory into the evaluation of the low-carbon sustainability and green operation benefits. Bai et al. [19] constructed Public-Private Partnership (PPP) project's sustainability risk factor system based on the fuzzy comprehensive evaluation model (FCEM). The results showed that the model was reasonable for assessing the sustainability risk level of PPP projects. Li et al. [20] proposed a qualitative and 
quantitative comprehensive risk assessment method combining fuzzy mathematics and grey system theory to analyzed Chinese overseas refinery project. Zhao et al. [21] proposed an evaluation index system for assessing the performance of Strong Smart Grid (SSG) from the perspective of sustainable development. The fuzzy TOPSIS method and the random analytic hierarchy process (AHP) were used to solve the deviation. Wu et al. [25] used the triangular intuitionistic fuzzy number (TIFN) to establish a comprehensive electric vehicle charging selection (EVCS) decision framework for residential communities. An evaluation system was constructed from the perspective of economic, social, and environmental of residential communities. They used fuzzy VlseKriterijumska Optimizacija I Kompromisno Resenje (fuzzy-VIKOR) method to evaluate the comprehensive EVCS site of the residential community. The results of the study showed that the EVCS site of the Sijiqing community in Haidian District is the best site. Zhang [26] used interval intuitionistic fuzzy numbers (IVIFN) to represent the inaccurate evaluation of the best alternative to photovoltaic cells. Xu et al. [27] proposed a new method to check the consistency of intuitive preferences and optimized the fuzzy values and attributes of classical AHP and intuitionistic fuzzy AHP (IFAHP). The example proved that IFAHP can be used to deal with more complex problems. Gao et al [28] used IFAHP to evaluated the port competitiveness of Quanzhou Port and pointed out directions for the future development. Dai et al [29] applied fuzzy group ideal point method to evaluate the sustainable development of power grid enterprises, and the results showed that the proposed method have the best performance.

In summary, based on these literature studies, we believe that traditional intuitionistic fuzzy analytic hierarchy process (IFAHP) has certain limitations. Firstly, the AHP relies too much on the subjectivity of experts; secondly, the fuzzy analytic hierarchy process (FAHP) cannot accurately express the abandonment or hesitation. Therefore, it is not suitable to deal with the problem of low-carbon sustainability and green operation benefits evaluation of power generation enterprises involving multiple different dimensions. Therefore, we propose an intuitionistic fuzzy comprehensive analytic hierarchy process based on improved dynamic hesitation degree (D-IFAHP) to achieve the effectiveness of low-carbon sustainability and green operation benefits evaluation of power generation enterprises.

With the advancement of intelligent algorithms, more and more simple artificial intelligence algorithms are applied in the field of comprehensive evaluation. The extreme learning machine (ELM) is essentially a single hidden layer neural network algorithm. ELM does not need to be adjusted during the execution, and only the weight of the hidden layer needs to be adjusted. Therefore, ELM has been widely used in recent years. Sun et al. [30] proposed a hybrid model based on principal component analysis (PCA) and regularized extreme learning machine, and made $\mathrm{CO}_{2}$ emissions prediction in China. Sun et al. [31] used the particle swarm optimization algorithm to optimize the input weight and threshold of the extreme learning machine, which improved the accuracy of the prediction and the operation speed of the algorithm. Li et al. [32] used the kernel learning function to optimize the extreme learning machine algorithm. The influence factor obtained by the grey correlation degree were input into the prediction algorithm to realize the prediction of carbon emission in the Beijing-Tianjin-Hebei region. Guo et al. [33] proved that the RELM can improve its robustness and has more accurate prediction capabilities. Therefore, we also apply RELM intelligent algorithm to achieve the intelligent and generalization performance of low-carbon sustainability and green operation benefits evaluation of power generation enterprises.

\section{Constructing an Evaluation Indicator System of Low-Carbon Sustainability and Green Operation Benefits of Power Generation Enterprises}

\subsection{Evaluation Indicator System Construction}

In this paper, the evaluation indicator system construction includes the following steps: (1) Determine preliminary evaluation indicators

According to many literature studies, four dimensions of economic development, operational production, resources and environmental protection, and green market trading were selected. Initially, 35 evaluation indicators including quantitative and qualitative were selected. 
(2) Ensure final evaluation indicator

In this study, the qualitative indicators were selected by the Delphi expert evaluation method, and many power system experts were invited. Each evaluation index was scored from 0 to 100 according to its importance. The higher the score, the higher the importance of the index. If the score of the indicator given by the expert $\mathrm{i}(\mathrm{i}=1,2,3,4,5 \ldots)$ is lower than 50 , the indicator will be abandoned. The indicators that are not important to evaluation of the low-carbon sustainability and green operation benefit evaluation index system for the power generation enterprise will be abandoned.

(3) Establish final evaluation indicator system

According to the expert assessment, the scores of some indicators are lower than the given value, and they are abandoned. All indicators and their scores are shown in Table A1 of Appendix A. Finally, an evaluation indicator system is established, as shown in Figure 1. 


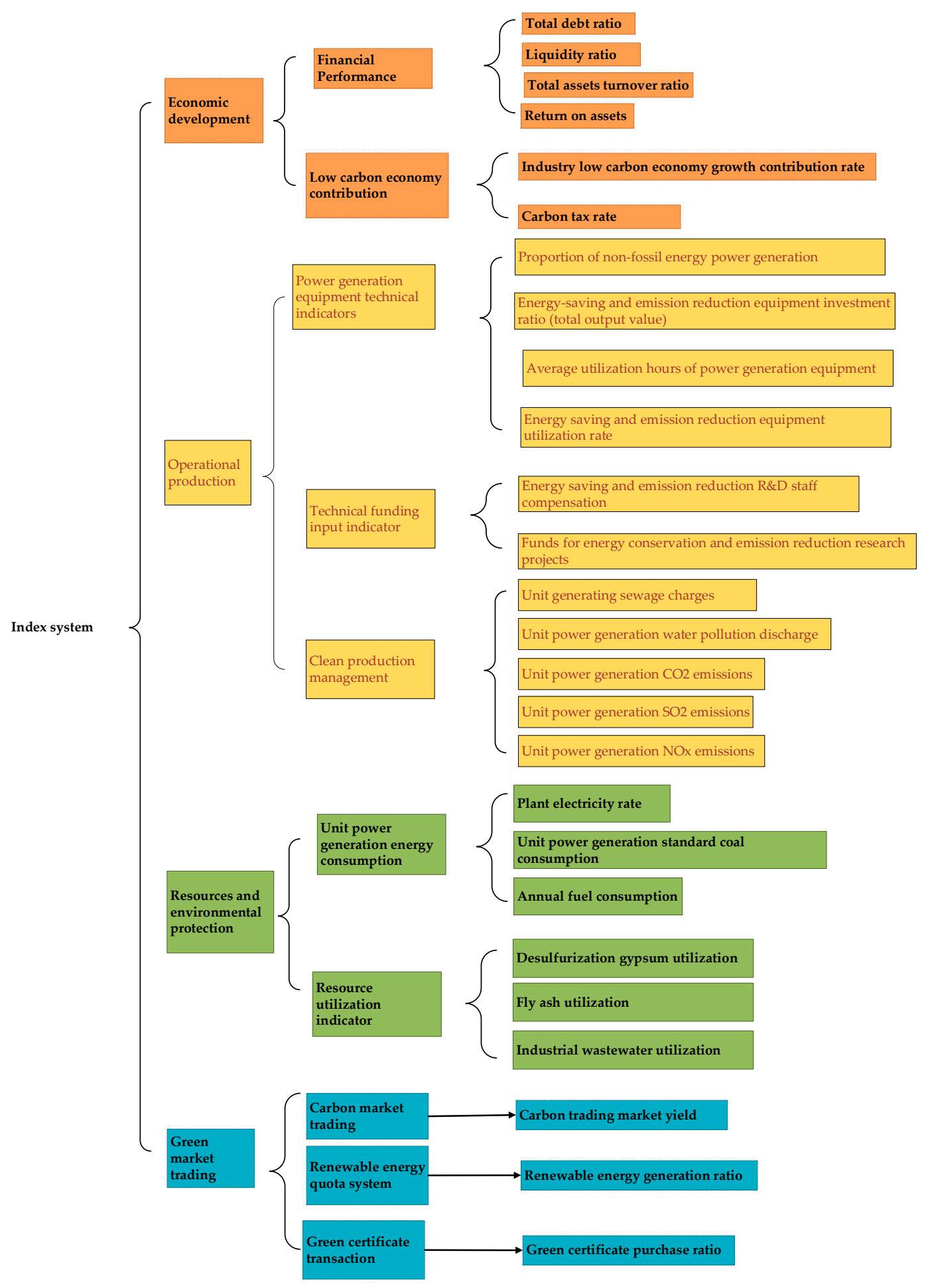

Figure 1. Low-carbon sustainability and green operation benefits evaluation index system of power generation enterprises.

\subsection{Indicator Description}

\subsubsection{Economic Development}

As a core dimension of low-carbon sustainability and green operation benefits evaluation, high-quality management capabilities can provide strong support for power generation enterprises' low-carbon sustainability and green operation benefits. 
Therefore, in the process of selecting indicators, we mainly select financial management indicators that are closely related to the daily operation of power generation companies. The specific explanation is shown in Table 1.

Table 1. Economic development indicators.

\begin{tabular}{cc}
\hline Indicator & Description \\
\hline Total debt ratio (A1) & $\begin{array}{c}\text { The ability to use creditors to provide funds for business } \\
\text { activities }\end{array}$ \\
\hline Liquidity ratio (A2) & The ability to repay short-term debt \\
\hline Total assets turnover ratio (A3) & Net income/Average total assets \\
\hline Return on assets (A4) & Net profit per unit of assets \\
\hline $\begin{array}{c}\text { Industry low carbon economy growth } \\
\text { contribution rate (A5) }\end{array}$ & $\begin{array}{c}\text { The output value of the cleaning unit/Total output value } \\
\text { of the industry }\end{array}$ \\
\hline Carbon tax rate (A6) & Carbon tax cost/Total tax \\
\hline
\end{tabular}

\subsubsection{Operational Production}

The operational production indicators are an important part of the low-carbon sustainability and green operation benefits evaluation, covering the most-level three-level indicators, and extracting evaluation indicators from the daily operations of power generation companies. The indicators are explained in Table 2.

Table 2. Operational production indicators.

\begin{tabular}{cc}
\hline Indicator & Description \\
\hline $\begin{array}{c}\text { Proportion of non-fossil energy power generation (B1) } \\
\text { Energy-saving and emission reduction equipment } \\
\text { investment ratio (B2) }\end{array}$ & $\begin{array}{c}\text { Non-fossil energy unit generating capacity/Total } \\
\text { generating capacity }\end{array}$ \\
\hline $\begin{array}{c}\text { Emission-reducing equipment/Total equipment } \\
\text { cost of the enterprise }\end{array}$ \\
$\begin{array}{c}\text { Average utilization hours of power generation } \\
\text { equipment (B3) }\end{array}$ & $\begin{array}{c}\text { Operating hours of average power generation } \\
\text { equipment capacity under full load operating } \\
\text { conditions }\end{array}$ \\
\hline $\begin{array}{c}\text { Energy saving and emission reduction equipment } \\
\text { utilization rate (B4) }\end{array}$ & $\begin{array}{c}\text { Energy-saving and emission reduction power } \\
\text { generation equipment full-load operation hours }\end{array}$ \\
\hline $\begin{array}{c}\text { Energy saving and emission reduction R\&D staff } \\
\text { compensation (B5) }\end{array}$ & $\begin{array}{c}\text { Labor cost of energy saving and personnel } \\
\text { emission reduction R\&D }\end{array}$ \\
\hline $\begin{array}{c}\text { Funds for energy conversation and emission } \\
\text { reduction research projects (B6) }\end{array}$ & $\begin{array}{c}\text { Project cost of energy saving and emission } \\
\text { reduction technology research and development }\end{array}$ \\
\hline Unit generating sewage charges (B7) & Production of pollutants per unit of electric power \\
\hline Unit power generation water pollution discharge (B8) & $\begin{array}{c}\text { Produce polluted water discharged by one unit of } \\
\text { electric power }\end{array}$ \\
\hline Unit power generation $\mathrm{CO}_{2}$ emissions (B9) & Production of a unit of $\mathrm{CO}_{2}$ emissions \\
\hline Unit power generation $\mathrm{SO}_{2}$ emissions (B10) & Production of a unit of $\mathrm{SO}_{2}$ emissions \\
\hline Unit power generation $\mathrm{NO}_{\mathrm{x}}$ emissions (B11) & Production of a unit of $\mathrm{NO}_{\mathrm{x}}$ emissions \\
\hline
\end{tabular}

\subsubsection{Resources and Environmental Protection}

Resources and environmental protection focus on the ability of power generation companies in terms of green operating income. The indicators are explained in Table 3. 
Table 3. Resources and environmental protection indicators.

\begin{tabular}{|c|c|}
\hline Indicator & Description \\
\hline Plant electricity rate $(\mathrm{C} 1)$ & Variable power consumption/Power generation per unit time \\
\hline $\begin{array}{l}\text { Unit power generation standard coal } \\
\text { consumption }(\mathrm{C} 2)\end{array}$ & One unit of electric power/Consumption of standard coal \\
\hline Unit power generation oil consumption (C3) & One unit of electric power/Consumption of standard oil \\
\hline Desulfurization gypsum utilization (C4) & $\begin{array}{c}\text { Annual utilization of desulfurized gypsum/Total annual } \\
\text { production }\end{array}$ \\
\hline Fly ash utilization (C5) & Ability to utilize fly ash resources \\
\hline Industrial wastewater utilization (C6) & Ability to treat industrial wastewater \\
\hline
\end{tabular}

\subsubsection{Green Market Trading}

Along with the development of green market trading, the activeness of power generation enterprises in China's green trading market, such as the carbon emissions trading market and the green certificate market, can effectively reflect the operational efficiency of low-carbon sustainability and green operation benefits. The specific explanation is shown in Table 4.

Table 4. Green market trading indicators.

\begin{tabular}{cc}
\hline Indicator & Description \\
\hline Carbon trading market yield (D1) & Participation in the carbon emissions market \\
\hline Renewable energy generation ratio (D2) & Production of renewable energy power \\
\hline Green certificate purchase ratio (D3) & Participation in green certificate market \\
\hline
\end{tabular}

\section{Methodology}

We apply the intuitionistic fuzzy analytic hierarchy process optimized by dynamic hesitation degree (D-IFAHP) and RELM to comprehensively evaluate the low-carbon sustainability and green operation benefits of power generation enterprises.

\subsection{Intuitionistic Fuzzy Analytic Hierarchy Process Optimized by Dynamic Hesitation Degree (D-IFAHP)}

Bulgarian scholar Atanassov et al. [22] proposed the definition of intuitionistic fuzzy sets and basic arithmetic rules, based on the theory, we propose the intuitionistic fuzzy analytic hierarchy process optimized by dynamic hesitation degree (D-IFAHP).

Definition 1. A is Intuitionistic fuzzy number, $\mu_{A}(x)$ and $v_{A}(x)$ are respectively the membership and non-affiliation of element $x$ in $X$ that is a non-empty set.

$$
\begin{gathered}
A=\left\{\left\langle x, \mu_{A}(x), v_{A}(x)\right\rangle \mid x \in X\right\} \\
\mu_{A}: X \rightarrow[0,1], x \in X \rightarrow \mu_{A}(x) \in[0,1] \\
v_{A}: X \rightarrow[0,1], x \in X \rightarrow v_{A}(x) \in[0,1]
\end{gathered}
$$

And they meet the conditions as follows.

$$
0 \leq \mu_{A}(x)+v_{A}(x) \leq 1, x \in X
$$

Definition 2. $\pi_{A}(x)$ is the degree of hesitation.

$$
\pi_{A}(x)=1-\mu_{A}(x)-v_{A}(x), x \in X
$$


Definition 3. $\alpha=\left(\mu_{\alpha}, v_{\alpha}\right), \alpha_{1}=\left(\mu_{\alpha_{1}}, v_{\alpha_{1}}\right)$ and $\alpha_{2}=\left(\mu_{\alpha_{2}}, v_{\alpha_{2}}\right)$ are all intuitionistic fuzzy numbers, and the calculation rules are as follows.

$$
\begin{gathered}
\alpha_{1}+\alpha_{2}=\left(\mu_{\alpha_{1}}+\mu_{\alpha_{2}}-\mu_{\alpha_{1}} \mu_{\alpha_{2}}, v_{\alpha_{1}} v_{\alpha_{2}}\right) \\
\alpha_{1} \alpha_{2}=\left(\mu_{\alpha_{1}} \mu_{\alpha_{2}}, \mu_{\alpha_{1}}+\mu_{\alpha_{2}}-v_{\alpha_{1}} v_{\alpha_{2}}\right)
\end{gathered}
$$

Then, the steps of the intuitionistic fuzzy analytic hierarchy process are as follows.

Step 1: Constructing an intuitionistic fuzzy judgment matrix.

$$
\begin{gathered}
R=\left(r_{i j}\right)_{n \times n} \\
r_{i j}=\left(\mu_{i j}, v_{i j}\right) \\
\pi_{i j}=1-\mu_{i j}-v_{i j}
\end{gathered}
$$

In the formula, $i$ and $j$ represent the rows and columns of the intuitionistic fuzzy judgment matrix.

Step 2: Calculating the final score and ensure the scale. In order to quantify the importance of indicators, we apply the intuitionistic fuzzy scale [24] to describe it, which has been shown in Table 5 .

Table 5. Intuitionistic fuzzy scale of low-carbon sustainability and green operation benefits of power generation enterprises.

\begin{tabular}{cc}
\hline Meaning & Scale \\
\hline$i$ is exceedingly superior to $j$ & $(0.90,0.10,0.00)$ \\
\hline$i$ is strongly superior to $j$ & $(0.80,0.15,0.05)$ \\
\hline$i$ is obviously superior to $j$ & $(0.70,0.20,0.10)$ \\
\hline$i$ is slightly superior to $j$ & $(0.60,0.25,0.15)$ \\
\hline$i$ is equivalent to factor $j(i \neq j)$ & $(0.50,0.30,0.20)$ \\
\hline$j$ is slightly superior to $i$ & $(0.40,0.45,0.15)$ \\
\hline$j$ is obviously superior to $i$ & $(0.30,0.60,0.10)$ \\
\hline$j$ is strongly superior to $i$ & $(0.20,0.75,0.05)$ \\
\hline$j$ is exceedingly superior to $i$ & $(0.10,0.90,0.00)$ \\
\hline
\end{tabular}

Step 3: Checking consistency. The distance consistency test of the intuitionistic fuzzy judgment matrix is as follows,

$$
d(\bar{R}, R)=\frac{1}{2(n-1)(n-2)} \sum_{i=1}^{n} \sum_{j=1}^{n}\left(\left|\bar{\mu}_{i j}-\mu_{i j}\right|+\left|\bar{v}_{i j}-v_{i j}\right|+\left|\bar{\pi}_{i j}-\pi_{i j}\right|\right)
$$

(1) when $j>i$, let $\bar{r}_{i j}=\left(\bar{\mu}_{i j}, \bar{v}_{i j}\right)$,

$$
\begin{gathered}
\bar{\mu}_{i j}=\frac{\sqrt[j-i-1]{\prod_{t=i+1}^{j-1} \mu_{i t} \mu_{t j}}}{\sqrt[j-i-1]{\prod_{t=i+1}^{j-1} \mu_{i t} \mu_{t j}}+\sqrt[j-i-1]{\prod_{t=i+1}^{j-1}\left(1-\mu_{i t}\right)\left(1-\mu_{t j}\right)}}, j>i+1 \\
\bar{v}_{i j}=\frac{\sqrt[j-i-1]{\prod_{t=i+1}^{j-1} v_{i t} v_{t j}}}{\sqrt[j-i-1]{\prod_{t=i+1}^{j-1} v_{i t} v_{t j}}+\sqrt[j-i-1]{\prod_{t=i+1}^{j-1}\left(1-v_{i t}\right)\left(1-v_{t j}\right)}}, j>i+1
\end{gathered}
$$


(2) when $j=i+1$,

$$
\bar{r}_{i j}=\left(\mu_{i j}, v_{i j}\right)
$$

(3) when $j<i$

$$
\bar{r}_{i j}=\left(\bar{v}_{i j}, \bar{\mu}_{i j}\right)
$$

Step 4: Correcting the consistency. Changing the intuitionistic fuzzy consistency judgment matrix by adjusting different iterative parameters until it finally passes the consistency test. The parameter range is iterating at 0.01 from 0 .

$$
\begin{aligned}
& \widetilde{\mu}_{i j}=\frac{\left(\mu_{i j}\right)^{1-\sigma}\left(\bar{\mu}_{i j}\right)^{\sigma}}{\left(\mu_{i j}\right)^{1-\sigma}\left(\bar{\mu}_{i j}\right)^{\sigma}+\left(1-\mu_{i j}\right)^{1-\sigma}\left(1-\bar{\mu}_{i j}\right)^{\sigma}}, i, j=1,2, \ldots, n \\
& \widetilde{v}_{i j}=\frac{\left(v_{i j}\right)^{1-\sigma}\left(\bar{v}_{i j}\right)^{\sigma}}{\left(v_{i j}\right)^{1-\sigma}\left(\widetilde{v}_{i j}\right)^{\sigma}+\left(1-v_{i j}\right)^{1-\sigma}\left(1-\widetilde{v}_{i j}\right)^{\sigma}}, i, j=1,2, \ldots, n
\end{aligned}
$$

Step 5: Bringing the corrected result into the Formula (11) for consistency check until it finally passes the test.

$$
d(\widetilde{R}, R)=\frac{1}{2(n-1)(n-2)} \sum_{i=1}^{n} \sum_{j=1}^{n}\left(\left|\widetilde{\mu}_{i j}-\mu_{i j}\right|+\left|\widetilde{v}_{i j}-v_{i j}\right|+\left|\widetilde{\pi}_{i j}-\pi_{i j}\right|\right)
$$

Step 6: Calculating the indicator weight,

$$
\omega_{i}=\left[\frac{\sum_{j=1}^{n} \bar{\mu}_{i j}}{\sum_{i=1}^{n} \sum_{j=1}^{n}\left(1-\bar{v}_{i j}\right)}, 1-\frac{\sum_{j=1}^{n}\left(1-\bar{v}_{i j}\right)}{\sum_{i=1}^{n} \sum_{j=1}^{n} \bar{\mu}_{i j}}\right], i=1,2, \ldots, n
$$

Step 7: Obtaining the dynamic hesitation degree. In order to improve the adaptability, a penalty mechanism is proposed in the paper to adjust the hesitation degree.

$$
\pi_{i j}^{\prime}=\left(1-\frac{n_{\pi}}{N_{\pi}}\right) \pi_{i j}
$$

In the formula, $N_{\pi}$ is the total number of indicators, $n_{\pi}$ is the performance of low-carbon sustainability and green operation benefits.

Step 8: Evaluating low-carbon sustainability and green operation of power generation enterprises,

$$
\begin{aligned}
& \omega_{1} \otimes \omega_{2}=\left(\mu_{\omega 1} \mu_{\omega 2}, v_{\omega 1}+v_{\omega 2}-v_{\omega 1} v_{\omega 2}\right) \\
& \omega_{1} \oplus \omega_{2}=\left(\mu_{\omega 1}+\mu_{\omega 2}-\mu_{\omega 1} \mu_{\omega 2}, v_{\omega 1} v_{\omega 2}\right)
\end{aligned}
$$

The weight of the second-level indicators and the final weight are as follows,

$$
\begin{gathered}
\omega\left(C_{i}\right)=\omega_{B_{k}} \otimes \omega_{C_{i}}, k=1,2, \ldots, m ; i=1,2, \ldots, n \\
W=\stackrel{\substack{i+1 \\
n}}{\oplus} \omega\left(C_{i}\right), i=1,2, \ldots, n
\end{gathered}
$$

Step 9: After completing the above calculation steps, the final comprehensive evaluation is carried out, which is as follows,

$$
\rho(W)=0.5(1+\pi w)(1-\mu w)
$$

In the formula, $\pi \omega$ is the hesitation degree and $\mu \omega$ is the membership of the weighted calculation. 
We divide the low-carbon sustainability and green operation efficiency grades of power generation enterprises into I, II, III, IV, V, which is as shown in Table 6.

Table 6. Low-carbon sustainability and green operation benefits rating of power generation enterprises.

\begin{tabular}{cccccc}
\hline Evaluation Level & V & IV & III & II & I \\
\hline Score & {$[0.9,1]$} & {$[0.8,0.9)$} & {$[0.6,0.8)$} & {$[0.45,0.6)$} & {$[0,0.45)$} \\
\hline
\end{tabular}

\subsection{Extreme Learning Machine Algorithm Optimized by RBF Kernel Function}

Extreme learning machine is a new single hidden layer feed-forward neural network algorithm invented by Huang [34] which has the advantages of high speed. It has the advantages of high learning efficiency and strong fitting ability [33]. The topological structure of the extreme learning machine is shown in Figure 2.

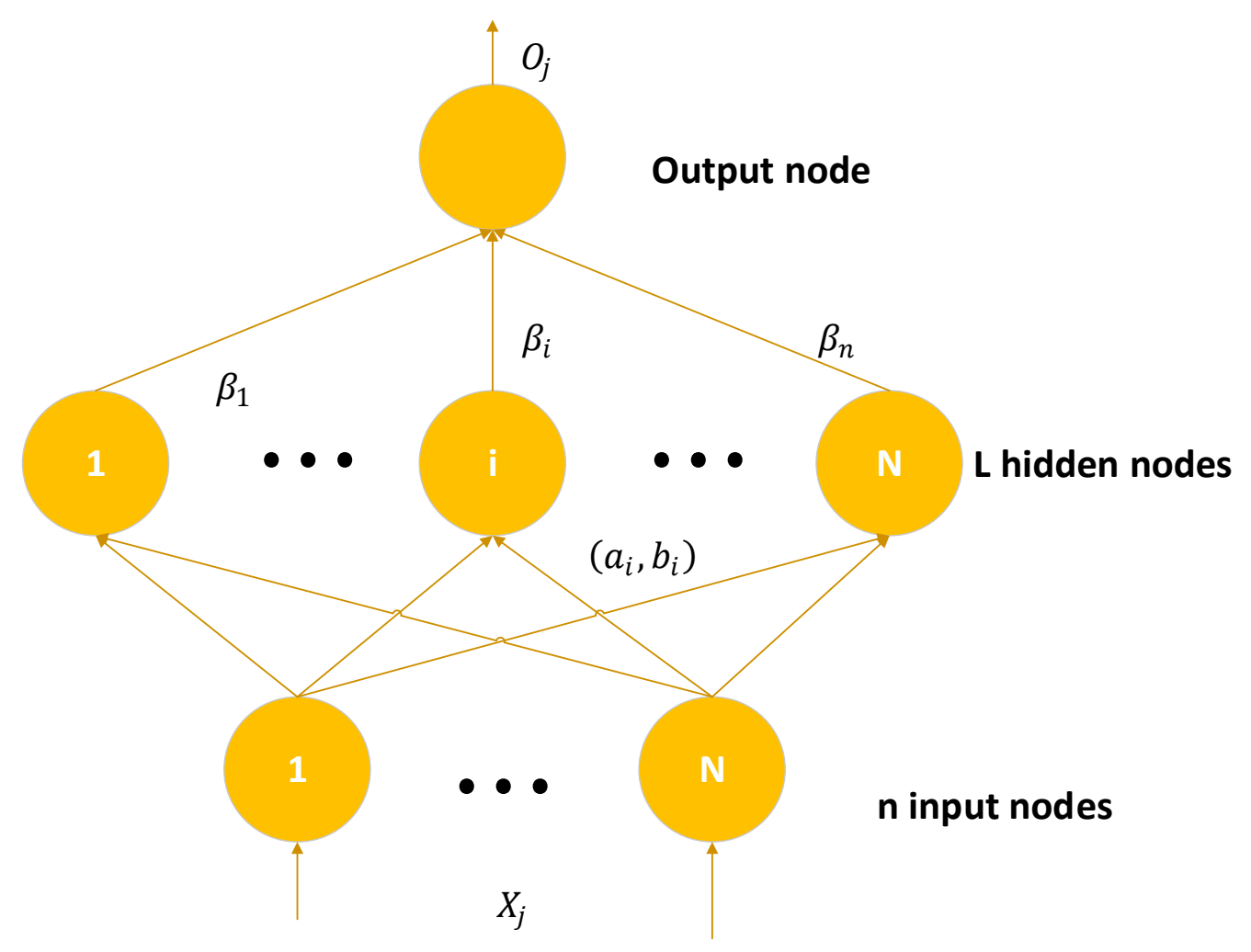

Figure 2. The topological structure of the extreme learning machine algorithm.

The operation of the extreme learning machine is as follows,

For a single hidden layer neural network, assuming there are $N$ arbitrary samples $\left(X_{i}, T_{i}\right)$, where $X_{i}=\left[x_{i 1}, x_{i 2}, \ldots x_{i n}\right]^{T} \in R^{n}, T_{i}=\left[t_{i 1}, t_{i 2}, \ldots t_{i n}\right]^{T} \in R^{m} . X_{i}$ is factor samples set and $T_{i}$ is target set.

A neural network with hidden layers $h(x)$ can be expressed as [35],

$$
\sum_{i=1}^{L} \gamma_{i} f\left(W_{i} \cdot X_{j}+b_{i}\right)=O_{j}, j=1,2 \ldots, n
$$

In the formula, $f(x)$ is the activation function, $W_{i}=\left[w_{i 1}, w_{i 2}, \ldots w_{i n}\right]^{T}$ is input weight, $\gamma_{i}$ is output weight, and $b_{i}$ is the offset of the hidden layer unit. 
Because the single hidden layer map $h(x)$ in extreme learning machine algorithm has the same effect as the RBF kernel function $K\left(x_{i}, x_{j}\right)$, we replace the single hidden layer map $h(x)$ by $K\left(x_{i}, x_{j}\right)$. Kernel matrix $\Omega_{E L M}$ is defined according to the Mercer condition,

$$
\Omega_{E L M}=H H^{T}=h\left(x_{i}\right) h\left(x_{j}\right)=K\left(x_{i}, x_{j}\right)
$$

According to the standard optimization principle, the original objective function can be expressed as,

$$
\min L_{p}=\frac{1}{2} \omega^{2}+\frac{1}{2} C \sum_{i=1}^{n} \xi_{i}^{2}
$$

In the formula, $C$ is a regular coefficient and $\xi_{i}$ is a training error.

According to the KKT theory (Karush-Kuhn-Tucker conditions), the original objective function can be transformed into,

$$
L_{p_{\text {kelm }}}=\frac{1}{2} \omega^{2}+\frac{1}{2} C \sum_{i=1}^{n} \xi_{i}{ }^{2}-\sum_{i=1}^{n} \eta_{i}\left(\psi\left(x_{i}\right) \omega-y_{i}+\xi_{i}\right)
$$

In the formula, $\eta_{i}$ is the Lagrange operator, $\psi\left(x_{i}\right)$ is original objective function.

The output of the RELM algorithm is,

$$
\omega=\sum_{i=1}^{n} \eta_{i} \psi\left(x_{i}\right)^{T}=\psi^{T} \eta
$$

In the formula, $\mathrm{C} \xi_{i}=\eta_{i}, \psi\left(x_{i}\right) \omega-y_{i}+\xi_{i}=0$.

\subsection{The Flow Chart of Evaluation Process}

In summary, the overall process consists of three modules, which includes an evaluation indicator system module, an intuitionistic fuzzy comprehensive analytic hierarchy process based on improved dynamic hesitation degree (D-IFAHP) module and the RELM module. The overall flow chart is shown in Figure 3: 


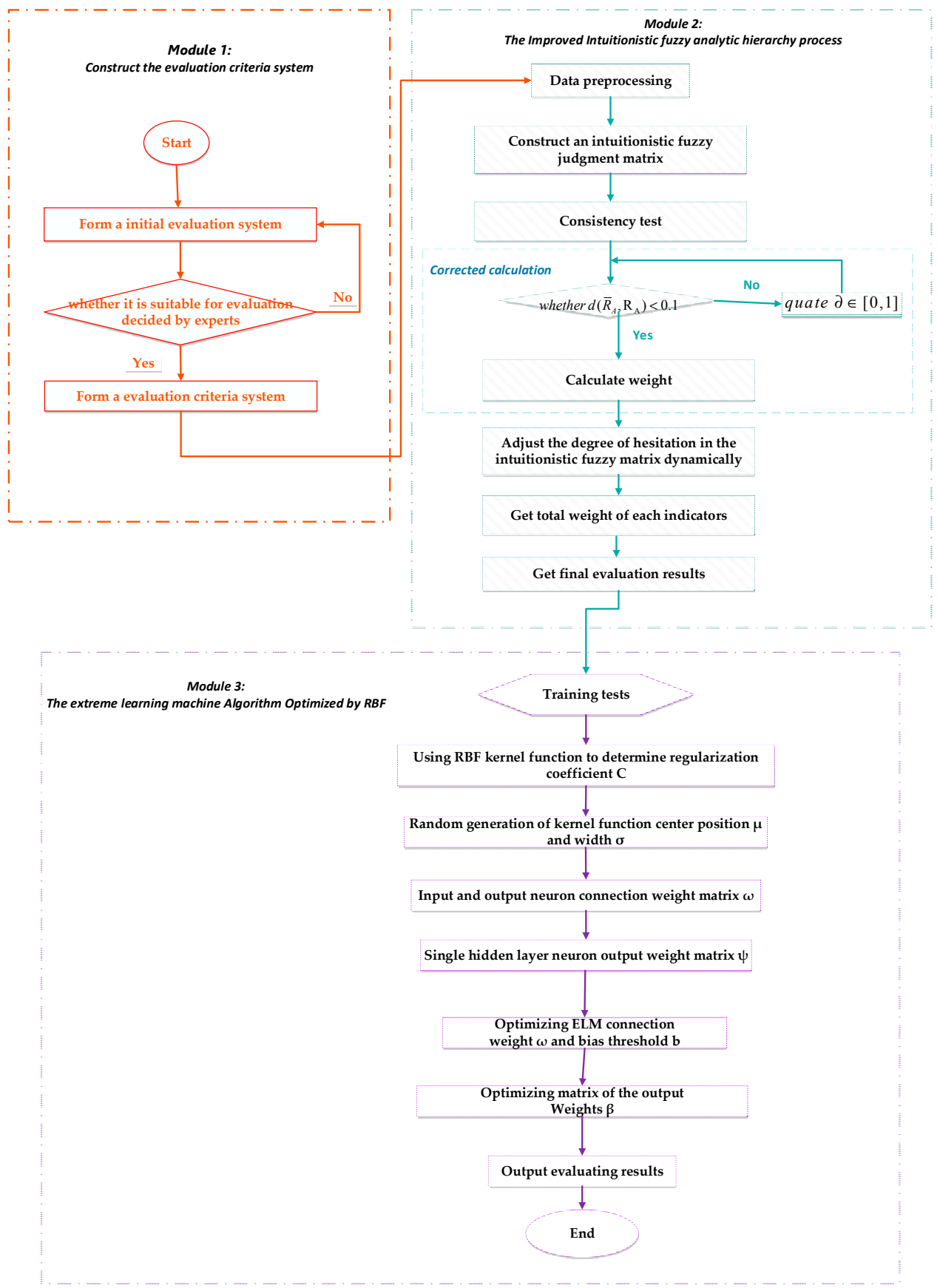

Figure 3. Flow chart of comprehensive evaluation of low-carbon sustainability and green operation benefits to power generation enterprises.

\section{Case Study and Discussion}

We select five power generation enterprises (1)-(5) in East China, North China, and South China and sort them by D-IFAHP. Then, we compare ranking results with other evaluation methods. Finally, we input the results of D-IFAHP to the training set of RELM algorithm to realize the evaluation process more intelligent. 


\subsection{Analysis of Low-Carbon Sustainability and Green Operation Benefits Based on D-IFAHP}

Qualitative indicators are converted into quantitative indicators by using expert scoring. We invite several experts to score $0-100$ and use the average as the final score of the indicator. We display analysis details of enterprise (1) as follows.

According to the initial data of enterprise (1) and the scores of experts, the intuitionistic fuzzy judgment matrix of enterprise (1) is calculated. By arithmetically averaging the index preference relations given by experts, the intuition fuzzy preference relationship of both first and second level indicators are finally obtained. Some details are as shown in Tables 7 and 8, other details are shown in Tables A2 and A3 of Appendix A:

Table 7. Intuition fuzzy preference relationship of first-level indicators.

\begin{tabular}{ccccc}
\hline & A & B & C & D \\
\hline A & $(0.50,0.30,0.20)$ & $(0.40,0.45,0.15)$ & $(0.50,0.30,0.20)$ & $(0.50,0.30,0.20)$ \\
B & $(0.70,0.20,0.10)$ & $(0.50,0.30,0.20)$ & $(0.50,0.30,0.20)$ & $(0.60,0.25,0.15)$ \\
C & $(0.50,0.30,0.20)$ & $(0.30,0.60,0.10)$ & $(0.50,0.30,0.20)$ & $(0.30,0.60,0.10)$ \\
D & $(0.40,0.45,0.15)$ & $(0.40,0.45,0.15)$ & $(0.60,0.25,0.15)$ & $(0.50,0.30,0.20)$ \\
\hline
\end{tabular}

Table 8. Intuitionistic fuzzy preference relationship of green market trading indicators.

\begin{tabular}{cccc}
\hline & D1 & D2 & D3 \\
\hline D1 & $(0.50,0.30,0.20)$ & $(0.40,0.45,0.15)$ & $(0.50,0.30,0.20)$ \\
D2 & $(0.40,0.45,0.15)$ & $(0.50,0.30,0.20)$ & $(0.40,0.45,0.15)$ \\
D3 & $(0.20,0.75,0.05)$ & $(0.30,0.60,0.10)$ & $(0.50,0.30,0.20)$ \\
\hline
\end{tabular}

According to Formulas (9)-(17), the consistency judgment matrix of enterprise (1) can be obtained:

$$
\bar{R}_{1}=\left[\begin{array}{llll}
(0.50,0.30,0.20) & (0.42,0.46,0.12) & (0.43,0.34,0.23) & (0.49,0.23,0.28) \\
(0.46,0.42,0.12) & (0.50,0.30,0.20) & (0.52,0.35,0.13) & (0.39,0.33,0.28) \\
(0.35,0.46,0.19) & (0.35,0.53,0.12) & (0.50,0.30,0.20) & (0.38,0.48,0,14) \\
(0.28,0.41,0.31) & (0.33,0.39,0.28) & (0.48,0.38,0.86) & (0.50,0.30,0.20)
\end{array}\right]
$$

Calculate the distance between $R_{1}$ and $\bar{R}_{1}$ to get $d\left(\bar{R}_{1}, R_{1}\right)=0.2038>0.1$, which is faili $\omega_{1} \omega_{2} \mathrm{ng}$ the consistency test. It need further set the parameters to adjust distance. Let $\sigma=0.45$ and use (18)-(24) to adjust the distance, so we get:

$$
\widetilde{R}_{1}=\left[\begin{array}{llll}
(0.50,0.30,0.20) & (0.42,0.46,0.12) & (0.49,0.34,0.17) & (0.51,0.32,0.17) \\
(0.46,0.42,0.12) & (0.50,0.30,0.20) & (0.52,0.33,0.15) & (0.53,0.29,0.18) \\
(0.44,0.39,0.17) & (0.42,0.44,0.14) & (0.50,0.30,0.20) & (0.38,0.48,0,14) \\
(0.36,0.46,0.18) & (0.40,0.41,0.19) & (0.52,0.35,0.13) & (0.50,0.30,0.20)
\end{array}\right]
$$

After calculation, $d\left(\widetilde{R}_{1}, R_{1}\right)=0.0824<0.1$. So, the matrix $\widetilde{R}_{1}$ passes the consistency test. Then $\widetilde{R}_{1}$ is substituted into (19) to calculate the first-level indicator weight:

$$
\omega_{1}=(0.24,0.69)
$$

Similarly, based on the each-level indicator weight, the total weight of each indicator.

$$
\omega_{t}=\omega_{1} \otimes \omega_{2} \otimes \omega_{3}=(0.24,0.69) \otimes(0.52,0.53) \otimes(0.31,0.63)=(0.03,0.94)
$$

The total weight of the enterprise (1) can be obtained in Table 9 . 
Table 9. Total weight of A company.

\begin{tabular}{|c|c|c|c|}
\hline First-Level $\left(\omega_{1}\right)$ & Second-Level $\left(\omega_{2}\right)$ & Third-Level $\left(\omega_{3}\right)$ & Total Weight $\left(\omega_{t}\right)$ \\
\hline \multirow{5}{*}{$(0.24,0.69)$} & \multirow{3}{*}{$(0.52,0.53)$} & $(0.31,0.63)$ & $(0.03,0.94)$ \\
\hline & & $(0.28,0.61)$ & $(0.03,0.94)$ \\
\hline & & $(0.21,0.52)$ & $(0.03,0.93)$ \\
\hline & \multirow{2}{*}{$(0.36,0.34)$} & $(0.43,0.41)$ & $(0.03,0.88)$ \\
\hline & & $(0.40,0.38)$ & $(0.03,0.87)$ \\
\hline \multirow{4}{*}{$(0.21,0.71)$} & \multirow{2}{*}{$(0.42,0.41)$} & $(0.52,0.53)$ & $(0.04,0.91)$ \\
\hline & & $(0.35,0.34)$ & $(0.03,0.88)$ \\
\hline & \multirow{2}{*}{$(0.45,0.44)$} & $(0.47,0.46)$ & $(0.04,0.90)$ \\
\hline & & $(0.40,0.38)$ & $(0.03,0.89)$ \\
\hline \multirow{8}{*}{$(0.18,0.66)$} & \multirow{4}{*}{$(0.36,0.71)$} & $(0.22,0.72)$ & $(0.01,0.97)$ \\
\hline & & $(0.23,0.72)$ & $(0.01,0.97)$ \\
\hline & & $(0.14,0.62)$ & $(0.01,0.96)$ \\
\hline & & $(0.17,0.64)$ & $(0.01,0.96)$ \\
\hline & \multirow{2}{*}{$(0.27,0.59)$} & $(0.45,0.45)$ & $(0.02,0.92)$ \\
\hline & & $(0.42,0.41)$ & $(0.02,0.92)$ \\
\hline & \multirow{2}{*}{$(0.20,0.50)$} & $(0.49,0.48) b$ & $(0.01,0.91)$ \\
\hline & & $(0.34,0.31)$ & $(0.01,0.88)$ \\
\hline \multirow{5}{*}{$(0.19,0.67)$} & \multirow{3}{*}{$(0.47,0.46)$} & $(0.32,0.65)$ & $(0.02,0.93)$ \\
\hline & & $(0.21,0.52)$ & $(0.01,0.91)$ \\
\hline & & $(0.28,0.60)$ & $(0.02,0.93)$ \\
\hline & \multirow{2}{*}{$(0.40,0.38)$} & $(0.44,0.50)$ & $(0.03,0.89)$ \\
\hline & & $(0.36,0.34)$ & $(0.02,0.86)$ \\
\hline
\end{tabular}

After collecting enterprise (1) total weight information for fuzzy information, we substitute it to (24), and get:

$$
\begin{gathered}
W_{1}=\oplus_{j=1}^{22} \omega_{j}=(0.03,0.94) \oplus(0.03,0.94) \oplus(0.02,0.93) \oplus(0.03,0.88) \oplus(0.03,0.87) \oplus \\
(0.04,0.91) \oplus(0.03,0.88) \oplus(0.04,0.90) \oplus(0.03,0.89) \oplus(0.01,0.97) \\
\oplus(0.01,0.97) \oplus(0.01,0.96) \oplus(0.01,0.96) \oplus(0.02,0.92) \oplus(0.02,0.92) \\
\oplus(0.01,0.91) \oplus(0.01,0.88) \oplus(0.02,0.93) \oplus(0.01,0.91) \oplus(0.02,0.93) \\
\oplus(0.03,0.89) \oplus(0.02,0.86) \\
=(0.45,0.16)
\end{gathered}
$$

Similarly, information aggregation for enterprises (2), (3), (4), and (5) can also be obtained:

$$
\begin{aligned}
& W_{2}=\oplus_{j=1}^{22} \omega_{j}=(0.51,0.07) \\
& W_{3}=\oplus_{j=1}^{22} \omega_{j}=(0.52,0.09) \\
& W_{4}=\oplus_{j=1}^{22} \omega_{j}=(0.52,0.10) \\
& W_{5}=\oplus_{j=1}^{22} \omega_{j}=(0.57,0.12)
\end{aligned}
$$


Substituting the above aggregated results into (25), the final evaluation results are shown in Table 10.

Table 10. Power generation enterprises energy-saving emission reduction sustainable operation efficiency score results.

\begin{tabular}{cccccc}
\hline Enterprises & (1) & (2) & (3) & (4) & (5) \\
\hline Score & 0.38 & 0.33 & 0.37 & 0.30 & 0.34 \\
\hline Sort & 1 & 4 & 2 & 5 & 3 \\
\hline
\end{tabular}

5.2. Comparative Analysis of Low-Carbon Sustainability and Green Operation Benefits Based on D-IFAHP, IFAHP, and FAHP

In order to further verify the proposed D-IFAHP has better performance in flexibility and practicability, we apply the same data input to the traditional IFAHP method and the FAHP method; all evaluation results are shown in Table 11 and Figure 4:

Table 11. Comprehensive evaluation value of different evaluation methods.

\begin{tabular}{cccc}
\hline \multirow{2}{*}{ Enterprises } & \multicolumn{3}{c}{ Comprehensive Evaluation Value } \\
\cline { 2 - 4 } & IFAHP & D-IFAHP & FAHP \\
\hline (1) & 0.3819 & 0.3819 & 0.3886 \\
\hline (2) & 0.3348 & 0.3304 & 0.3544 \\
\hline (3) & 0.3772 & 0.3772 & 0.3840 \\
\hline (4) & 0.3356 & 0.3012 & 0.3553 \\
\hline (5) & 0.3397 & 0.3452 & 0.3596 \\
\hline
\end{tabular}
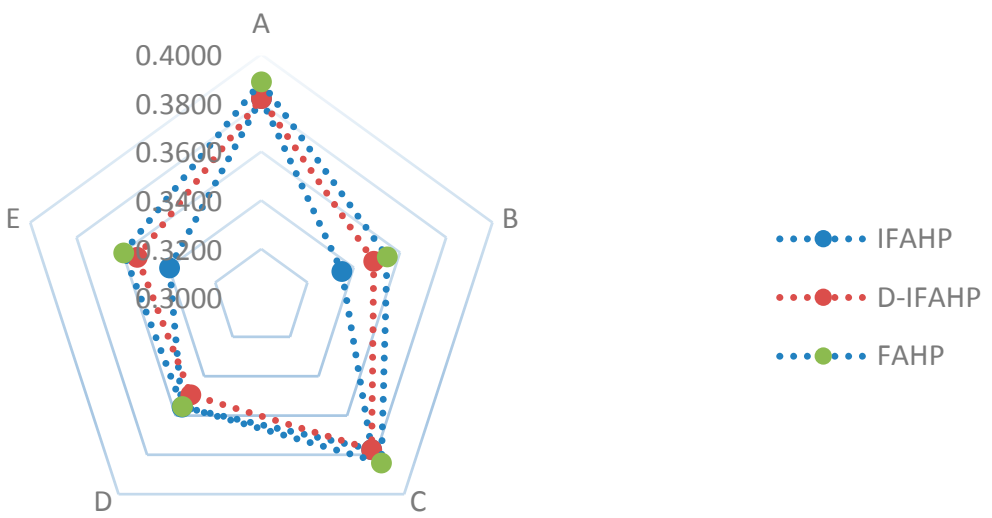

Figure 4. Comparison of comprehensive evaluation values of different evaluation methods.

5.3. Low-Carbon Sustainability and Green Operation Benefits of Power Generation Enterprises Based on D-IFAHP-RELM Evaluation Model

Based on the D-IFAHP evaluation result, we used sample data of the five power generation enterprises as the input data of RELM model. The parameters of RELM evaluation model are shown in Table 12: 
Table 12. Improved extreme learning machine algorithm optimized by RBF kernel function (RELM) model parameter set.

\begin{tabular}{cc}
\hline Parameter & Value \\
\hline Regularization coefficient $C$ & 0.5 \\
RBF kernel parameter & {$[0.15,0.25]$} \\
Number of nodes in hidden layer & $2^{10}$ \\
\hline
\end{tabular}

In order to compare the rationality and superiority, we compared the assessment results of artificial neural network (ANN), ELM, and RELM, training results of different evaluation models are shown in Figure 5.

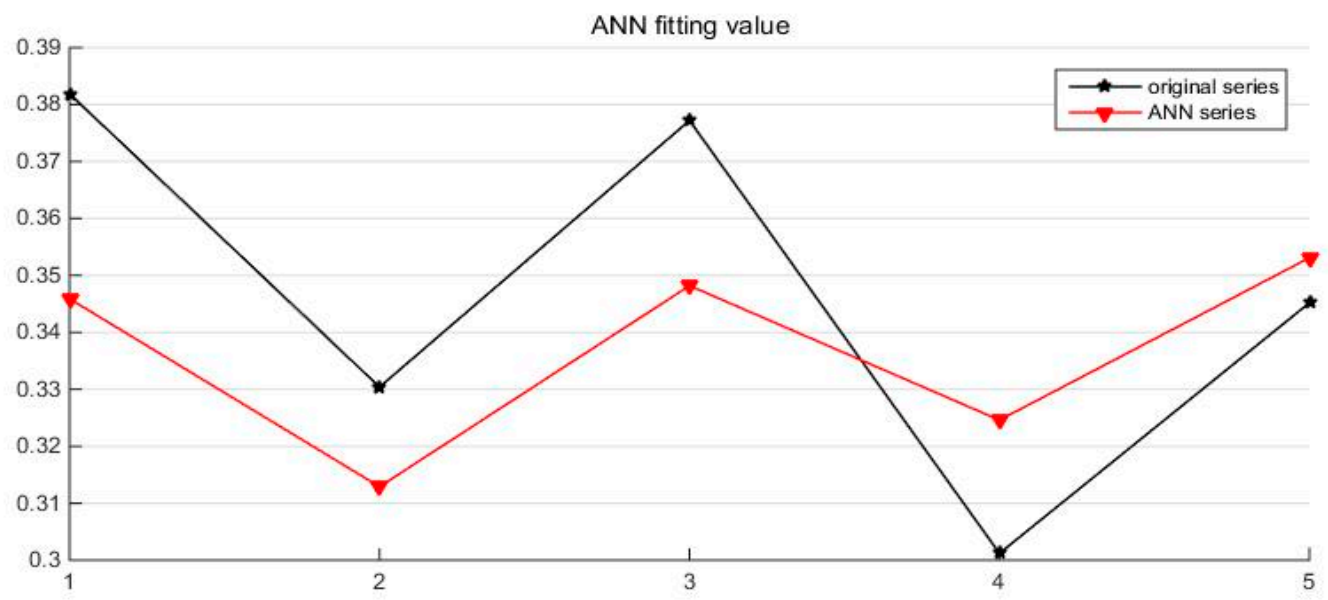

(a)

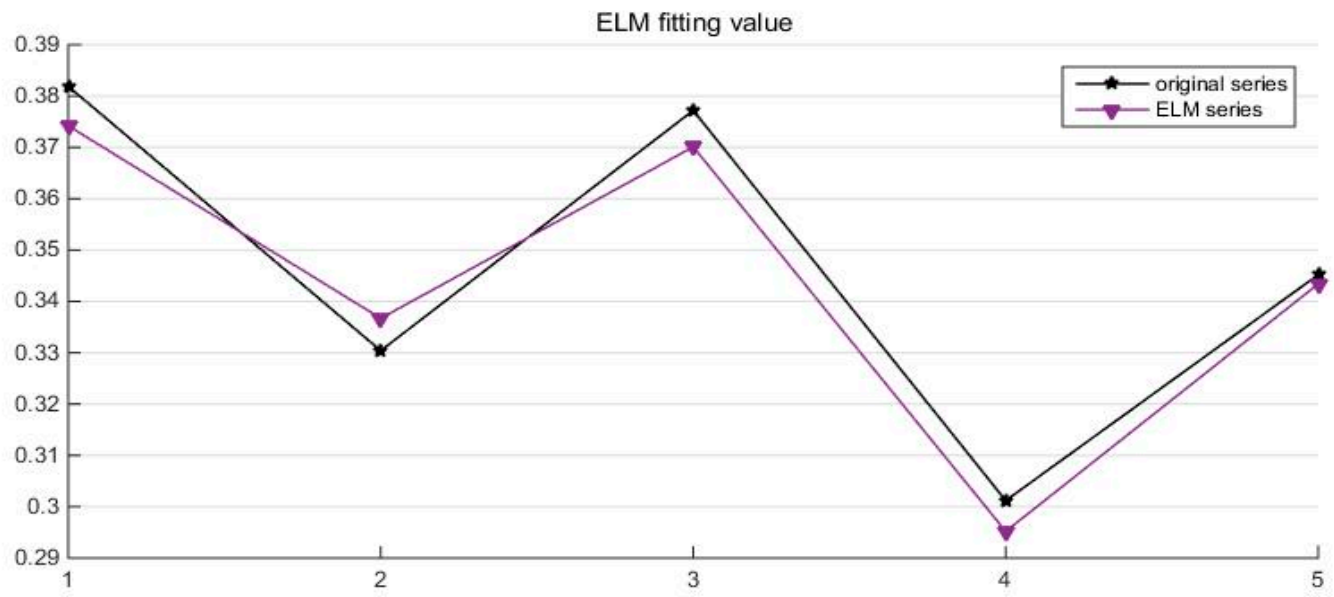

(b)

Figure 5. Cont. 


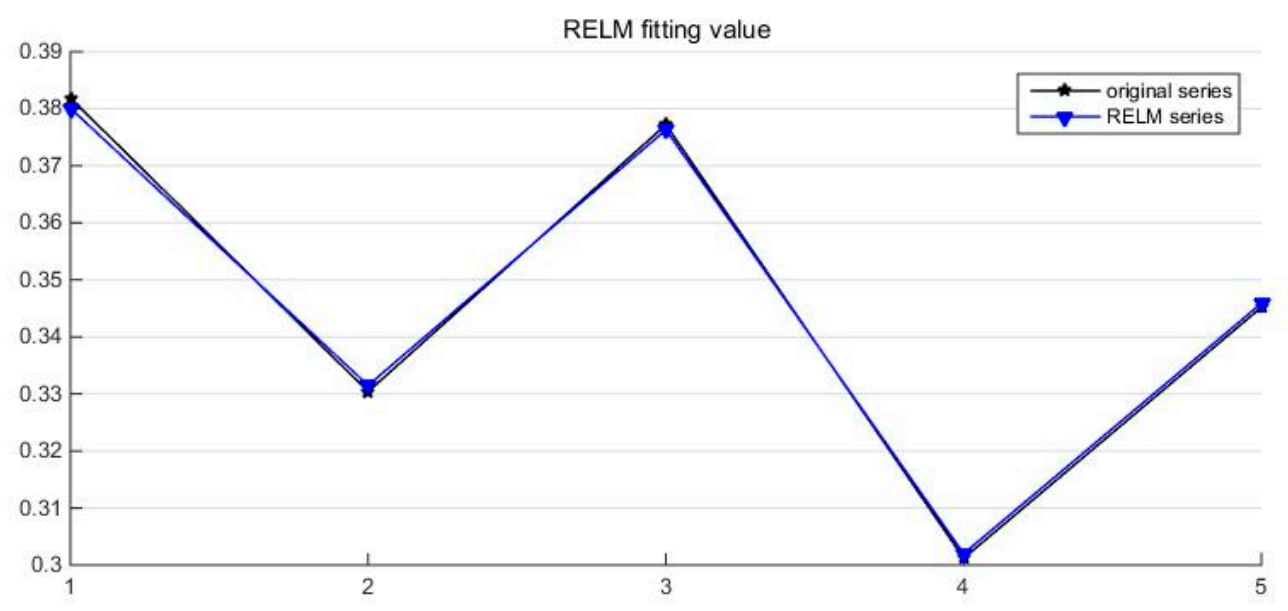

(c)

Figure 5. Training results of RELM and ELM evaluation models: (a) Training results of artificial neural network (ANN) model; (b) Training results of ELM model; (c) Training results of RELM model.

The relative error of ANN, ELM, and RELM models are shown in Table 13.

Table 13. The relative error of ELM model and evaluation results.

\begin{tabular}{cccccccc}
\hline \multirow{2}{*}{ Enterprises } & \multirow{2}{*}{$\begin{array}{c}\text { D-IFAHP } \\
\text { Evaluation Result }\end{array}$} & \multicolumn{2}{c}{ ANN } & \multicolumn{2}{c}{ RELM } & \multicolumn{2}{c}{ ELM } \\
\cline { 3 - 7 } & & $\begin{array}{l}\text { Training } \\
\text { Results }\end{array}$ & RE (\%) & $\begin{array}{c}\text { Training } \\
\text { Results }\end{array}$ & RE (\%) & $\begin{array}{c}\text { Training } \\
\text { Results }\end{array}$ & RE (\%) \\
\hline (1) & 0.3819 & 0.3459 & -9.4265 & 0.3801 & -0.4713 & 0.3742 & -2.0162 \\
(2) & 0.3304 & 0.3129 & -5.2966 & 0.3315 & 0.3329 & 0.3367 & 1.9068 \\
(3) & 0.3772 & 0.3482 & -7.6882 & 0.3763 & -0.2386 & 0.3701 & -1.8823 \\
(4) & 0.3012 & 0.3246 & 7.7689 & 0.302 & 0.2656 & 0.2952 & -1.9920 \\
(5) & 0.3452 & 0.3531 & 2.2885 & 0.3459 & 0.2028 & 0.3434 & -0.5214 \\
\hline
\end{tabular}

\subsection{Discussions}

Based on the case study comparison, some discussion results can be obtained:

(1) Table 11 and Figure 4 show that the evaluation results of the FAHP and IFAHP methods cannot clearly show difference between the indicators of the sustainable operation efficiency of energy-saving and emission reduction of power generation enterprises. Compared with the D-IFAHP and IFAHP methods, the resolution of D-IFAHP is higher. Therefore, D-IFAHP can better reflect the difference in the sustainable operational benefits of energy conservation and emission reduction of five power generation enterprises.

(2) From Figure 5 and Table 13, we can conclude that average relative error of the RELM evaluation model is the smallest, so the test results of which are more accurate. Therefore, it can be used in low-carbon sustainability and green operation benefits of power generation enterprises.

(3) If the sample data is small, we can directly use the D-IFAHP evaluation model proposed in the paper for evaluation. However, when the evaluation sample increases, continuing to use D-IFAHP will increase the difficulty and time cost of the calculation. The D-IFAHP-RELM evaluation model proposed in this paper can solve this problem. Firstly, some samples are evaluated by D-IFAHP, and this part of the sample is used as the input of RELM model of training sets. After obtaining the optimal parameters of the model, the RELM model is used to complete the evaluation procedure of the remaining samples, which can avoid complex calculation processes. 


\section{Conclusions}

In order to evaluate the low-carbon sustainability and green operation benefits of power generation enterprises, we chose 26 indicators from economic development, operational production, resources and environmental protection, and green market trading based on the extensive literature research. Through the dynamic hesitancy degree improved intuitionistic fuzzy AHP method (D-IFAHP), we improved the traditional intuitionistic fuzzy AHP method by the rationality of objectivity. Then, the RELM intelligent algorithm is applied to avoid complex calculation processes.

Main results of this paper are as follows:

(1) The shortcomings of the traditional IFAHP and FAHP are proved, which is lack of objectivity. Therefore, decision makers cannot express abstention or hesitancy. Based on the IFAHP, a new parameter (nonmembership function) is added and then a new fuzzy set is formed, which has stronger flexibility. Empirical analysis proves the accuracy of low-carbon sustainability and green operation benefits evaluation of D-IFAHP.

(2) RELM intelligent algorithm can improve the accuracy and speed of traditional ELM algorithm. The evaluation results based on D-IFAHP can quickly be applied as input of RELM model, which can simplify the calculation process of large amount of sample data and reduce the time cost.

(3) D-IFAHP- RELM model is suitable for low-carbon sustainability and green operation benefits for power generation enterprises. The application of RELM algorithm will greatly improve the speed of evaluation. As long as the index value of the company is used as the input of the RELM algorithm, the evaluation grades and results of each company can be obtained quickly. Therefore, the low-carbon sustainability and green operation benefits evaluation system proposed in this paper has effective operation and heterogeneity and practical performance, which can effectively improve the sustainable profit of power companies and ultimately realize China's energy transformation.

Author Contributions: In this research activity, all authors were involved in the data collection and preprocessing phase, model constructing, empirical research, results analysis and discussion, and manuscript preparation. All authors have approved the submitted manuscript.

Funding: This research was funded by the National Natural Science Foundation of China, grant number (71573084), the Beijing Municipal Social Science Foundation, grant number (16JDYJB044), the 2018 key Projects of Philosophy and Social Sciences Research, Ministry of Education, China (18JZD032), and the Fundamental Research Funds for the Central Universities (2019QN067).

Acknowledgments: The completion of this paper has been helped by many teachers and classmates. We would like to express our gratitude to them for their help and guidance.

Conflicts of Interest: The authors declare no conflict of interest. 


\section{Appendix A}

Table A1. Average scores of preliminary indicators.

\begin{tabular}{|c|c|c|c|}
\hline Dimension & Indicators & Average Score & Whether to Keep \\
\hline \multirow{6}{*}{$\begin{array}{c}\text { Economic } \\
\text { development }\end{array}$} & Total debt ratio & 88.3 & $\sqrt{ }$ \\
\hline & Liquidity ratio & 84.6 & $\sqrt{ }$ \\
\hline & Total assets turnover ratio & 86.9 & $\sqrt{ }$ \\
\hline & Return on assets & 87.8 & $\sqrt{ }$ \\
\hline & $\begin{array}{l}\text { industry low carbon economy growth } \\
\text { contribution }\end{array}$ & 89.3 & $\sqrt{ }$ \\
\hline & Carbon tax rate & 90.2 & $\sqrt{ }$ \\
\hline \multirow{15}{*}{$\begin{array}{l}\text { Operational } \\
\text { production }\end{array}$} & Proportion of non-fossil energy generation & 86.3 & $\sqrt{ }$ \\
\hline & $\begin{array}{l}\text { Energy-saving and emission reduction } \\
\text { equipment investment ratio }\end{array}$ & 78.5 & $\sqrt{ }$ \\
\hline & $\begin{array}{c}\text { Average utilization hours of power generation } \\
\text { equipment }\end{array}$ & 77.3 & $\sqrt{ }$ \\
\hline & $\begin{array}{l}\text { Energy saving and emission reduction } \\
\text { equipment utilization rate }\end{array}$ & 75.6 & $\sqrt{ }$ \\
\hline & $\begin{array}{l}\text { Energy saving and emission reduction R\&D } \\
\text { staff compensation }\end{array}$ & 67.4 & $\sqrt{ }$ \\
\hline & $\begin{array}{l}\text { Funds for energy conversation and emission } \\
\text { reduction research projects }\end{array}$ & 68.5 & $\sqrt{ }$ \\
\hline & Unit generating sewage charges & 86.3 & $\sqrt{ }$ \\
\hline & $\begin{array}{l}\text { Unit power generation water pollution } \\
\text { discharge }\end{array}$ & 82.0 & $\sqrt{ }$ \\
\hline & Unit power generation $\mathrm{CO}_{2}$ emissions & 88.3 & $\sqrt{ }$ \\
\hline & Unit power generation $\mathrm{SO}_{2}$ emissions & 85.4 & $\sqrt{ }$ \\
\hline & Unit power generation $\mathrm{NO}_{\mathrm{x}}$ emissions & 83.7 & $\sqrt{ }$ \\
\hline & Energy-saving equipment usage rate & 73.1 & $\sqrt{ }$ \\
\hline & Environmental equipment investment rate & 49.4 & $\times$ \\
\hline & Unit power generation water withdrawal & 38.2 & $\times$ \\
\hline & Standard coal consumption rate & 44.7 & $\times$ \\
\hline \multirow{9}{*}{$\begin{array}{l}\text { Resources and } \\
\text { environmental } \\
\text { protection }\end{array}$} & Plant electricity rate & 86.4 & $\sqrt{ }$ \\
\hline & $\begin{array}{l}\text { Unit power generation standard coal } \\
\text { consumption }\end{array}$ & 82.5 & $\sqrt{ }$ \\
\hline & Annual fuel consumption & 81.6 & $\sqrt{ }$ \\
\hline & Desulfurization gypsum utilization & 83.4 & $\sqrt{ }$ \\
\hline & Fly ash utilization & 81.5 & $\sqrt{ }$ \\
\hline & Industrial wastewater utilization & 63.9 & $\sqrt{ }$ \\
\hline & Noise compliance rate & 20.5 & $\times$ \\
\hline & Pollutant discharge compliance rate & 49.9 & $\times$ \\
\hline & Desulfurization efficiency rate & 39.9 & $\times$ \\
\hline \multirow{4}{*}{$\begin{array}{l}\text { Green market } \\
\text { trading }\end{array}$} & Carbon trading market yield & 89.3 & $\sqrt{ }$ \\
\hline & Renewable energy generation ratio & 83.6 & $\sqrt{ }$ \\
\hline & Green certificate purchase ratio & 88.3 & $\sqrt{ }$ \\
\hline & Renewable energy quota ratio & 46.2 & $x$ \\
\hline
\end{tabular}


Table A2. Intuition fuzzy preference relationship of operational production indicators.

\begin{tabular}{|c|c|c|c|c|c|c|c|c|c|c|c|}
\hline & B1 & B2 & B3 & B4 & B5 & B6 & B7 & B8 & B9 & B10 & B11 \\
\hline B1 & $\begin{array}{l}0.50, \\
0.30 \\
0.20)\end{array}$ & $\begin{array}{l}0.40 \\
0.45, \\
0.15)\end{array}$ & $\begin{array}{l}0.50, \\
0.30 \\
0.20)\end{array}$ & $\begin{array}{l}0.50, \\
0.30, \\
0.20)\end{array}$ & $\begin{array}{l}0.50, \\
0.30, \\
0.20)\end{array}$ & $\begin{array}{l}0.30 \\
0.60 \\
0.10)\end{array}$ & $\begin{array}{l}0.50, \\
0.30, \\
0.20)\end{array}$ & $\begin{array}{l}0.30 \\
0.60 \\
0.10)\end{array}$ & $\begin{array}{l}0.50, \\
0.30, \\
0.20)\end{array}$ & $\begin{array}{l}0.50 \\
0.30 \\
0.20)\end{array}$ & $\begin{array}{l}0.50, \\
0.30, \\
0.20)\end{array}$ \\
\hline B2 & $\begin{array}{l}0.40, \\
0.45, \\
0.15)\end{array}$ & $\begin{array}{l}0.50 \\
0.30 \\
0.20)\end{array}$ & $\begin{array}{l}0.50 \\
0.30 \\
0.20)\end{array}$ & $\begin{array}{l}0.50, \\
0.30, \\
0.20)\end{array}$ & $\begin{array}{l}0.30, \\
0.60, \\
0.10)\end{array}$ & $\begin{array}{l}0.50 \\
0.30, \\
0.20)\end{array}$ & $\begin{array}{l}0.40, \\
0.45, \\
0.15)\end{array}$ & $\begin{array}{l}0.40 \\
0.45, \\
0.15)\end{array}$ & $\begin{array}{l}0.40, \\
0.45, \\
0.15)\end{array}$ & $\begin{array}{l}0.40 \\
0.45, \\
0.15)\end{array}$ & $\begin{array}{l}0.40, \\
0.45, \\
0.15)\end{array}$ \\
\hline B3 & $\begin{array}{l}0.50, \\
0.30, \\
0.20)\end{array}$ & $\begin{array}{l}0.30 \\
0.60 \\
0.10)\end{array}$ & $\begin{array}{l}0.40 \\
0.45, \\
0.15)\end{array}$ & $\begin{array}{l}0.30, \\
0.60, \\
0.10)\end{array}$ & $\begin{array}{l}0.50, \\
0.30, \\
0.20)\end{array}$ & $\begin{array}{l}0.40 \\
0.45, \\
0.15)\end{array}$ & $\begin{array}{l}0.50, \\
0.30, \\
0.20)\end{array}$ & $\begin{array}{l}0.50 \\
0.30, \\
0.20)\end{array}$ & $\begin{array}{l}0.50, \\
0.30, \\
0.20)\end{array}$ & $\begin{array}{l}0.50 \\
0.30, \\
0.20)\end{array}$ & $\begin{array}{l}0.50, \\
0.30, \\
0.20)\end{array}$ \\
\hline B4 & $\begin{array}{l}(0.30, \\
0.60, \\
0.10)\end{array}$ & $\begin{array}{l}(0.40 \\
0.45 \\
0.15)\end{array}$ & $\begin{array}{l}(0.50, \\
0.30, \\
0.20)\end{array}$ & $\begin{array}{l}(0.50, \\
0.30, \\
0.20)\end{array}$ & $\begin{array}{l}(0.30, \\
0.60, \\
0.10)\end{array}$ & $\begin{array}{l}(0.50 \\
0.30 \\
0.20)\end{array}$ & $\begin{array}{l}(0.30, \\
0.60, \\
0.10)\end{array}$ & $\begin{array}{l}(0.30 \\
0.60 \\
0.10)\end{array}$ & $\begin{array}{l}(0.50, \\
0.30, \\
0.20)\end{array}$ & $\begin{array}{l}(0.30 \\
0.60 \\
0.10)\end{array}$ & $\begin{array}{l}(0.40, \\
0.45, \\
0.15)\end{array}$ \\
\hline B5 & $\begin{array}{l}(0.50, \\
0.30, \\
0.20)\end{array}$ & $\begin{array}{l}(0.50 \\
0.30 \\
0.20)\end{array}$ & $\begin{array}{l}(0.30 \\
0.60, \\
0.10)\end{array}$ & $\begin{array}{l}(0.40, \\
0.45, \\
0.15)\end{array}$ & $\begin{array}{l}(0.50, \\
0.30, \\
0.20)\end{array}$ & $\begin{array}{l}(0.40 \\
0.45 \\
0.15)\end{array}$ & $\begin{array}{l}(0.40 \\
0.45, \\
0.15)\end{array}$ & $\begin{array}{l}(0.40 \\
0.45 \\
0.15) \\
\end{array}$ & $\begin{array}{l}(0.40, \\
0.45, \\
0.15)\end{array}$ & $\begin{array}{l}(0.40 \\
0.45, \\
0.15)\end{array}$ & $\begin{array}{l}(0.50, \\
0.30, \\
0.20)\end{array}$ \\
\hline B6 & $\begin{array}{l}(0.40, \\
0.45, \\
0.15)\end{array}$ & $\begin{array}{l}0.40 \\
0.45 \\
0.15) \\
\end{array}$ & $\begin{array}{l}(0.30, \\
0.60, \\
0.10)\end{array}$ & $\begin{array}{l}(0.50, \\
0.30, \\
0.20)\end{array}$ & $\begin{array}{l}(0.40, \\
0.45, \\
0.15)\end{array}$ & $\begin{array}{l}0.50 \\
0.30 \\
0.20) \\
\end{array}$ & $\begin{array}{l}(0.40, \\
0.45, \\
0.15)\end{array}$ & $\begin{array}{l}0.50 \\
0.30 \\
0.20) \\
\end{array}$ & $\begin{array}{l}(0.50, \\
0.30, \\
0.20)\end{array}$ & $\begin{array}{l}(0.40 \\
0.45, \\
0.15)\end{array}$ & $\begin{array}{l}(0.30, \\
0.60, \\
0.10)\end{array}$ \\
\hline B7 & $\begin{array}{l}(0.50, \\
0.30 \\
0.20)\end{array}$ & $\begin{array}{l}(0.40, \\
0.45, \\
0.15)\end{array}$ & $\begin{array}{l}(0.50, \\
0.30 \\
0.20)\end{array}$ & $\begin{array}{l}(0.40, \\
0.45, \\
0.15)\end{array}$ & $\begin{array}{c}(0.50, \\
0.30, \\
0.20)\end{array}$ & $\begin{array}{c}(0.50, \\
0.30 \\
0.20)\end{array}$ & $\begin{array}{l}(0.50 \\
0.30 \\
0.20)\end{array}$ & $\begin{array}{l}(0.60, \\
0.25, \\
0.15)\end{array}$ & $\begin{array}{c}(0.40, \\
0.45, \\
0.15)\end{array}$ & $\begin{array}{l}(0.50, \\
0.30 \\
0.20)\end{array}$ & $\begin{array}{c}(0.50, \\
0.30 \\
0.20)\end{array}$ \\
\hline B8 & $\begin{array}{l}(0.40, \\
0.45, \\
0.15)\end{array}$ & $\begin{array}{l}(0.50 \\
0.30 \\
0.20)\end{array}$ & $\begin{array}{l}(0.40, \\
0.45, \\
0.15)\end{array}$ & $\begin{array}{l}(0.50, \\
0.30, \\
0.20)\end{array}$ & $\begin{array}{l}(0.40, \\
0.45, \\
0.15)\end{array}$ & $\begin{array}{l}(0.50 \\
0.30 \\
0.20)\end{array}$ & $\begin{array}{l}(0.30, \\
0.60, \\
0.10)\end{array}$ & $\begin{array}{l}(0.30 \\
0.60 \\
0.10)\end{array}$ & $\begin{array}{l}(0.20, \\
0.75, \\
0.05)\end{array}$ & $\begin{array}{l}(0.30 \\
0.60 \\
0.10)\end{array}$ & $\begin{array}{l}(0.40, \\
0.45, \\
0.15)\end{array}$ \\
\hline B9 & $\begin{array}{l}(0.50, \\
0.30, \\
0.20)\end{array}$ & $\begin{array}{l}(0.30 \\
0.60 \\
0.10)\end{array}$ & $\begin{array}{l}(0.50, \\
0.30, \\
0.20)\end{array}$ & $\begin{array}{l}(0.40, \\
0.45, \\
0.15)\end{array}$ & $\begin{array}{l}(0.50, \\
0.30, \\
0.20)\end{array}$ & $\begin{array}{l}(0.30 \\
0.60 \\
0.10)\end{array}$ & $\begin{array}{l}(0.40, \\
0.45, \\
0.15)\end{array}$ & $\begin{array}{l}(0.50 \\
0.30 \\
0.20)\end{array}$ & $\begin{array}{l}(0.60, \\
0.25, \\
0.15)\end{array}$ & $\begin{array}{l}(0.30 \\
0.60 \\
0.10)\end{array}$ & $\begin{array}{l}(0.50, \\
0.30, \\
0.20)\end{array}$ \\
\hline B10 & $\begin{array}{l}(0.30, \\
0.60 \\
0.10)\end{array}$ & $\begin{array}{l}0.50, \\
0.30, \\
0.20)\end{array}$ & $\begin{array}{l}0.40, \\
0.45, \\
0.15)\end{array}$ & $\begin{array}{l}0.50, \\
0.30 \\
0.20)\end{array}$ & $\begin{array}{l}(0.50, \\
0.30 \\
0.20)\end{array}$ & $\begin{array}{l}(0.40 \\
0.45 \\
0.15)\end{array}$ & $\begin{array}{l}(0.50 \\
0.30 \\
0.20)\end{array}$ & $\begin{array}{l}(0.70 \\
0.20 \\
0.10)\end{array}$ & $\begin{array}{c}0.30 \\
0.60 \\
0.10)\end{array}$ & $\begin{array}{l}(0.40 \\
0.45, \\
0.15)\end{array}$ & $\begin{array}{l}0.50 \\
0.30 \\
0.20)\end{array}$ \\
\hline B11 & $\begin{array}{l}(0.40, \\
0.45 \\
0.15)\end{array}$ & $\begin{array}{l}(0.40 \\
0.45, \\
0.15)\end{array}$ & $\begin{array}{l}(0.30 \\
0.60 \\
0.10)\end{array}$ & $\begin{array}{l}(0.30, \\
0.60, \\
0.10)\end{array}$ & $\begin{array}{l}(0.40, \\
0.45, \\
0.15)\end{array}$ & $\begin{array}{l}(0.50 \\
0.30 \\
0.20)\end{array}$ & $\begin{array}{l}(0.30 \\
0.60 \\
0.10)\end{array}$ & $\begin{array}{l}(0.50 \\
0.30 \\
0.20)\end{array}$ & $\begin{array}{l}(0.30, \\
0.60 \\
0.10)\end{array}$ & $\begin{array}{l}(0.50, \\
0.30, \\
0.20)\end{array}$ & $\begin{array}{l}(0.30 \\
0.60 \\
0.10)\end{array}$ \\
\hline
\end{tabular}

Table A3. Intuition fuzzy preference relationship of resources and environmental protection indicators.

\begin{tabular}{ccccccc}
\hline & C1 & C2 & C3 & C4 & C5 & C6 \\
\hline C1 & $(0.40,0.45,0.15)$ & $(0.50,0.30,0.20)$ & $(0.30,0.60,0.10)$ & $(0.40,0.45,0.15)$ & $(0.40,0.45,0.15)$ & $(0.40,0.45,0.15)$ \\
\hline C2 & $(0.50,0.30,0.20)$ & $(0.40,0.45,0.15)$ & $(0.40,0.45,0.15)$ & $(0.50,0.30,0.20)$ & $(0.40,0.45,0.15)$ & $(0.40,0.45,0.15)$ \\
\hline C3 & $(0.30,0.60,0.10)$ & $(0.50,0.30,0.20)$ & $(0.50,0.30,0.20)$ & $(0.40,0.45,0.15)$ & $(0.50,0.30,0.20)$ & $(0.50,0.30,0.20)$ \\
\hline C4 & $(0.50,0.30,0.20)$ & $(0.50,0.30,0.20)$ & $(0.40,0.45,0.15)$ & $(0.50,0.30,0.20)$ & $(0.50,0.30,0.20)$ & $(0.30,0.60,0.10)$ \\
\hline C5 & $(0.40,0.45,0.15)$ & $(0.40,0.45,0.15)$ & $(0.50,0.30,0.20)$ & $(0.30,0.60,0.10)$ & $(0.40,0.45,0.15)$ & $(0.30,0.60,0.10)$ \\
\hline C6 & $(0.50,0.30,0.20)$ & $(0.50,0.30,0.20)$ & $(0.30,0.60,0.10)$ & $(0.30,0.60,0.10)$ & $(0.50,0.30,0.20)$ & $(0.30,0.60,0.10)$ \\
\hline
\end{tabular}

\section{References}

1. Wang, Q.; Jiang, R. Is China's economic growth decoupled from carbon emissions? J. Clean. Prod. 2019, 225, 1194-1208. [CrossRef]

2. Bao, C.; Xu, M.T. Cause and effect of renewable energy consumption on urbanization and economic growth in China's provinces and regions. J. Clean. Prod. 2019, 231, 483-493. [CrossRef]

3. Song, X.G.; Zhou, Y.X.; Jia, W. How do Economic Openness and R\&D Investment Affect Green Economic Growth?-Evidence from China. Resour. Conserv. Recycl. 2019, 146, 405-415.

4. Lu, W.L. Research on Safety Lean Management and Implementation Effect Evaluation Thermal Power Enterprise. Master's Thesis, North China Electric Power University, Beijing, China, 2017. 
5. Shi, Q.S.; Tu, N. The application of hierarchy gray assessment in safety evaluation of power plant. J. Shanghai Inst. Electr. Power 2005, 1, 81-84.

6. Li, C.; Yang, Z.X.; Song, L. Construction and application of synthetic safety assessment model for power plants. Comput. Eng. Appl. 2010, 2, 230-233.

7. Li, W.; Wang, J.; Niu, D.X. Competitive ability evaluation for generation enterprises based on combinational weight. J. North China Electr. Power Univ. 2006, 5, 93-96.

8. Li, H.Z.; He, H.F.; Guo, X. Evaluation of independent generation's competence after separation of grid and generation. Power Syst. Technol. 2004, 20,7-10.

9. Zhang, L.H.; Gu, R.; Wu, Y.F. The source and evaluation model on the competitiveness of generation enterprises. Value Eng. 2006, 2, 75-78.

10. Liu, L.Z. Opinion and Evaluation of Cleaner Production in Thermal Power Industry; Energy Environmental Protection: Hartford, CT, USA, 2011; Volume 1, pp. 62-64.

11. Ren, Y.L.; Liu, N.; Liu, H. A Comprehensive Evaluation of DEA of China's Thermal Power Industry Efficiency Turn towards the Coordinated development of electricity energy and environment. East China Econ. Manag. 2011, 4, 80-82.

12. Jia, H.J.; Haung, X.C.; Xie, Y.P. Assessment and Analysis of Cleaner Production Standard in the Power Plant Industry; Energy Environmental Protection: Hartford, CT, USA, 2010; Volume 2, pp. 54-57.

13. Chen, Q.X.; Zhou, T.R.; Kang, C.Q.; Xia, Q. An Assessment Model of Low-carbon Effect and Its Application to Energy Saving Based Generation Dispatching. Autom. Electr. Power Syst. 2009, 16, 24-29.

14. Shi, Y. Research on the Performance Evaluation of Energy-Saving and Emission Reduction in Electric Power Industry. Master's Thesis, North China Electric Power University, Beijing, China, 2010.

15. He, W.; Qin, N.; He, K.H.; Xu, F.L.; Wang, Y. Monitoring and evaluation of energy-saving and pollution reduction performance (ESPRP)and its coordination with economic benefit. Acta Sci. Circumstantiae 2010, 7, 1499-1509.

16. Liu, Q.Y. The Study on Comprehensive Evaluation about Energy-Saving and Emission Reduction Contribution Effect of Power Grid Enterprise. Master's Thesis, North China Electric Power University, Beijing, China, 2012.

17. Zhu, C.Y. Donghua Thermal Power Plant Energy Conservation Technology Path Design and Evalution. Master's Thesis, North China Electric Power University, Beijing, China, 2014.

18. Zhao, X.Y. Study on Performance Evaluation of Energy-Saving and Emission Reduction in Thermal Power Enterprises. Master's Thesis, North China Electric Power University, Beijing, China, 2017.

19. Bai, L.B.; Li, Y.; Du, Q.; Xu, Y.D. A Fuzzy Comprehensive Evaluation Model for Sustainability Risk Evaluation of PPP Projects. Sustainability 2017, 9, 1890. [CrossRef]

20. Li, H.; Dong, K.Y.; Jiang, H.D.; Sun, R.J.; Guo, X.Y.; Fan, Y.Q. Risk Assessment of China's Overseas Oil Refining Investment Using a Fuzzy-Grey Comprehensive Evaluation Method. Sustainability 2017, 9, 696. [CrossRef]

21. Zhao, H.R.; Li, N. Performance Evaluation for Sustainability of Strong Smart Grid by Using Stochastic AHP and Fuzzy TOPSIS Methods. Sustainability 2016, 8, 129. [CrossRef]

22. Atanassov, K.T. Intuitionistic Fuzzy Sets. Fuzzy Sets Syst. 1986, 20, 87-96. [CrossRef]

23. Atanassov, K.T. Remarks on the Intuitionistic Fuzzy Sets. Fuzzy Sets Syst. 1992, 51, 117-118. [CrossRef]

24. Atanassov, K.T. New Operations Defined over the Intuitionistic Fuzzy Sets. Fuzzy Sets Syst. 1994, 61, 137-142. [CrossRef]

25. Wu, Y.N.; Xie, C.; Xu, C.B.; Li, F. A Decision Framework for Electric Vehicle Charging Station Site Selection for Residential Communities under an Intuitionistic Fuzzy Environment: A Case of Beijing. Energies 2017, 10, 1270. [CrossRef]

26. Zhang, X.L. New Interval-Valued Intuitionistic Fuzzy Behavioral MADM Method and Its Application in the Selection of Photovoltaic Cells. Energies 2016, 9, 835. [CrossRef]

27. Xu, Z.S.; Liao, H. Intuitionistic Fuzzy Analytic Hierarchy Process. IEEE Trans. Fuzzy Syst. 2014, 22, 749-761. [CrossRef]

28. Gao, T.L.; Na, S.Y.; Dang, X.H.; Zhang, Y.L. Study of the Competitiveness of Quanzhou Port on the Belt and Road in China Based on a Fuzzy-AHP and ELECTRE III Model. Sustainability 2018, 10, 1253. [CrossRef]

29. Dai, S.Y.; Niu, D.X. Comprehensive Evaluation of the Sustainable Development of Power Grid Enterprises Based on the Model of Fuzzy Group Ideal Point Method and Combination Weighting Method with Improved Group Order Relation Method and Entropy Weight Method. Sustainability 2017, 9, 1900. 
30. Sun, W.; Wang, C.F.; Zhang, C.C. Factor analysis and forecasting of $\mathrm{CO}_{2}$ emissions in Hebei, using extreme learning machine based on particle swarm optimization. J. Clean. Prod. 2017, 162, 1095-1101. [CrossRef]

31. Sun, W.; Sun, J.Y. Prediction of carbon dioxide emissions based on principal component analysis with regularized extreme learning machine: The case of China. Environ. Eng. Res. 2017, 22, 302-311. [CrossRef]

32. Li, M.L.; Wang, W.; De, G.J.R.F.; Ji, X.H.; Tan, Z.F. Forecasting Carbon Emissions Related to Energy Consumption in Beijing-Tianjin-Hebei Region Based on Grey Prediction Theory and Extreme Learning Machine Optimized by Support Vector Machine Algorithm. Energies 2018, 11, 2475. [CrossRef]

33. Guo, B.X.; Li, J. Kernel extreme learning machine for indoor positioning in location finger printing. Comput. Eng. Appl. 2016, 52, 78-83.

34. Huang, G.B.; Bai, Z.; Kasun, L.L.C.; Vong, C.M. Local respective fields based extreme learning machine. IEEE Comput. Intell. 2015, 10, 18-29. [CrossRef]

35. Wu, J.J. Short-Term Wind Power Prediction Research Based on Extreme Learning Machine. Master's Thesis, North China Electric Power University, Beijing, China, 2017.

(C) 2019 by the authors. Licensee MDPI, Basel, Switzerland. This article is an open access article distributed under the terms and conditions of the Creative Commons Attribution (CC BY) license (http://creativecommons.org/licenses/by/4.0/). 